\title{
Effects of pre-sowing treatments on seed germination and Morphological growth of Acacia nilotica and Faidherbia albida
}

\author{
Efeitos de tratamentos pré-semeadura na germinação de sementes e \\ crescimento morfológico de Acacia nilotica e Faidherbia albida
}

\author{
Matoor Mohsin Gilani ${ }^{1,2}$, Irfan Ahmad ${ }^{2}$, Taimoor Hassan Farooq ${ }^{1,2}$, Pengfei Wu ${ }^{1}$, \\ Muhammad Sohail Yousaf', Muhammad Waqqas khan', Talha bin Yousaf ${ }^{2}$ \\ and Xiangqing $\mathrm{Ma}^{\mathbf{1}^{*}}$
}

\begin{abstract}
Resumo
As florestas são geradas por meios naturais e artificiais. No caso de regeneração artificial, as mudas são criadas em viveiros e transplantadas para o campo. Métodos de propagação sexual e assexuada são comumente usados para o crescimento de árvores. A maioria das árvores são propagadas por meios sexuais. Às vezes, sementes saudáveis não germinam mesmo após a disponibilidade de temperatura adequada, leve e suficiente. A dormência da semente é o fracasso da semente desenvolvida em germinar na situação apropriada. O objetivo do nosso estudo foi descobrir a melhor técnica adequada para quebrar a dormência das sementes de Acacia nilotica e Faidherbia albida. Para aumentar a germinação, foram utilizadas diferentes técnicas de queima de dormência, incluindo água quente, água fria, tratamento mecânico e ácido sulfúrico. Esta pesquisa foi conduzida em (RCBD) design de bloqueio aleatório completo e dados sobre germinação e outros fatores foram coletados semanalmente. Numerosos parâmetros morfológicos foram estudados. A porcentagem máxima de sobrevivência foi observada no tratamento de água quente, seguido do tratamento com água fria e tratamento mecânico. A percentagem máxima de germinação foi de 76,2 (\%) e foi observada em A.nilotica, enquanto que no mínimo 12,6 (\%) foi observado em F.albida. A percentagem de sobrevivência mais alta foi de $62,8 \%$ e mínima $8,8 \%$, altura máxima da planta de $9,99 \mathrm{~cm}$, enquanto a altura mínima foi de $2,39 \mathrm{~cm}$, o comprimento máximo da raiz foi de $8,09 \mathrm{~cm}$ e o mínimo de $2,12 \mathrm{~cm}$ foi registrado em A.nilotica e F.albida em todos os tratamentos. No nosso estudo, descobrimos que o tratamento de água quente foi a melhor técnica para a germinação de sementes de A. nilotica e $F$. albida.
\end{abstract}

Palavras-chave: Dormência; Germinação; Percentagem de sobrevivência; Ratio de raiz-disparo; Crescimento da planta; Acacia nilotica; Faidherbia albida

\begin{abstract}
Forests are generated by natural and artificial means. In case of artificial regeneration seedlings are raised in nurseries and transplanted to the field. Sexual and asexual propagation methods are commonly used for growing trees. Most of the trees are propagated by sexual means. Sometimes healthy seeds do not germinate even after the availability of proper temperature, light and sufficient moisture. Seed dormancy is the failure of the developed seed to germinate in the appropriate situation. Objective of our study was to discover the best suitable technique for breaking seed dormancy of Acacia nilotica and Faidherbia albida. To increase the germination, different dormancy breaking techniques were used including, hot water, cold water, mechanical and sulphuric acid treatment. This research was conducted in (RCBD) Randomized complete block design and data concerning germination and other factors were collected weekly. Numerous morphological parameters were studied. The maximum survival percentage was observed in hot water treatment followed by cold water treatment and mechanical treatment. Maximum germination percentage was $76.2(\%)$ and it was observed in A.nilotica whereas minimum $12.6(\%)$ was observed in F.albida. Highest survival percentage was $62.8 \%$ and minimum $8.8 \%$, maximum plant height $9.99 \mathrm{~cm}$ while minimum height was $2.39 \mathrm{~cm}$, maximum root length was $8.09 \mathrm{~cm}$ and minimum $2.12 \mathrm{~cm}$ was recorded in A.nilotica and F.albida in all treatments. From our study, we found that, hot water treatment was the best technique for seed germination of $A$. nilotica and $F$. albida seeds.
\end{abstract}

Keywords: Dormancy; Germination; Survival percentage; Root-shoot Ratio; Plant growth; Acacia nilotica; Faidherbia albida

1. College of Forestry, Fujian Agriculture and Forestry University. Fuzhou, China. lxymxq@126.com

2. Department of Forestry and Range management, University of Agriculture. Faisalabad, Pakistan.

Sci. For., Piracicaba, v. 47, n. 122, p. 374-382, jun. 2019

DOI: doi.org/10.18671/scifor.v47n122.20 


\section{INTRODUCTION}

Seed dormancy is known as failure of developed seed to grow in the appropriate situations (SCHMIDT, 2000). Dormancy of seed is helpful occasionally as it makes sure specie existence in most of the environments and allows it to grow. Acacia nilotica is a vital specie of the Fabaceae family that is commonly important tree in native areas and in exotic areas it is considered as a weed in the forest. It is extensively found in the countries like Pakistan, India, Yemen, Egypt, Burma, Israel and as a local specie in East, South and North of Africa. Formerly Faidherbia albida was known as Acacia albida. Germination of seed is stimulated by Smoke, Ash and high temperature (KEELEY; FOTHERINGHAM, 2000). Forest fire affects seed germination, mainly due to the influence on the inner side of the seeds for example physical influence or by chemical effect (VAN STANDEN et al., 2000). High temperature or prolonged interaction of some fire prone species can be lethal however seed contact with temperature within 80 and $120^{\circ} \mathrm{C}$ for some time showed improvement in the germination of seeds (RIVAS et al., 2006; ZULOAGA-AGUILAR et al., 2010). Through the uptake of water germination of seed starts and it finishes by the elongation of the developing axis of embryo (HOLDSWORTH et al., 2008). Methods which are usually used to break water resistant seed coat and to acquire continuous and rapid development are mechanical, chemical, sulphuric acid and hot water treatments (AREF et al., 2011; KARAGUZEL et al., 2004). For demanding moisture and appropriate growth temperature for germination some seeds require germination stimulants like karrikinolide in smoke and Gibberellic acid (NELSON et al., 2009). These germination stimulants are used to increase seed germination of numerous species (KULKARNI et al., 2007; MERRITT et al., 2006). Smoke is used to boost germination of seeds with fire-prone and non-fire prone environments (MERRITT et al., 2006). Cold stratification is vital in breaking the dormancy in several summer species of temperate climatic areas as their seeds spend the unfavorable cold winter in dormant condition (SCHUTZ, 1999). The objective of our study was to suggest the suitable technique for breaking the dormancy of the seeds of Acacia nilotica and Faidherbia albida. Comparison of different growth parameters of these two species were analyzed by mechanical and chemical treatments.

\section{MATERIALS AND METHODS}

\section{Plant Material}

The research was conducted in the experimental area of the Department of Forestry and Range Management, University of Agriculture, Faisalabad. Acacia nilotica and Faidherbia albida mature, fresh and uniform seeds were collected from Punjab Forestry Research Institute gatwala Faisalabad (PFRI). For this research sandy clay loam soil was chosen. Before putting it into the polythene bags air dried soil was sieved and mixed carefully. For this trial 400 polythene bags of size $(9$ " $\times 4$ ") were used. After every 6 days water was applied to the polythene bags.

\section{Description of treatments}

Control (T1), hot water (T2), cold water (T3), mechanical (T4) and sulphuric acid (T5) treatments were used. In control sowing, seeds were directly sown in the polythene bags without any treatment. In hot water treatment the water was boiled for 15 minutes then the seeds were treated with that hot water for further 15 minutes. Cold water was kept in refrigerator for 24 hours, after 12 hours the seeds were kept in cold water of $4^{\circ} \mathrm{C}$ for 12 hours. Mechanical scarification and piercing of the seed coat was done to encourage germination of the seeds. Seeds were cracked gently with the hammer to weaken the seed coat. In T5, seeds were treated with concentrated sulphuric acid $\left(\mathrm{H}_{2} \mathrm{SO}_{4}\right)(95 \%)$ for 10 minutes after that seeds were washed with distilled water for further 10 minutes and sown directly into the polythene bags. This trial was placed in 10 feet long and 4 feet wide nursery beds. Trail was covered with polythene sheet. Purpose of plastic sheet was to protect the plants from environmental extremes.

\section{Data collection}

Data about germination and other parameters were collected on every week and the trial was designed in (RCBD) Randomized complete block design. Germination of seedling was recorded after every six days. This was continued up to the time when no more germination was possible.

Sci. For., Piracicaba, v. 47, n. 122, p. 374-382, jun. 2019

DOI: doi.org/10.18671/scifor.v47n122.20 
Total number of germinated seeds was counted from each block and germination percentage was calculated by following formula:

$$
\text { Seed germination } \%=\frac{\text { Total number of germinated seed }}{\text { Total number of seed sown }}
$$

The total length (shoot and root) of the plants were measured with measuring tape and average was calculated to express the mean length of plant. Plants were taken out of there pots and fresh weight was taken with the help of electrical balance. While recording the dry weight; material was put into the paper bags and oven dried in windy oven at $65^{\circ} \mathrm{C}$ and then weighed with the help of electrical balance. Five plants were randomly selected from each treatment at the time of harvesting to measure the root/shoot ratio by dividing the root with shoot of the plants and average was calculated to express the mean length of plants. For statistical analysis, two-way analysis of variance (ANOVA) was performed with species in blocks. The least significant test (LSD) was used for treatments only for mean comparison.

\section{RESULTS}

\section{Germination percentage (\%)}

Germination of seed is a significant phase in the life of the plant. In some cases, delay in germination of seed could be due to the harsh environment and damaged seeds. When the competition of water and light is relatively low seeds may grow. Quiescence is another form of late germination which is rather different from the seed dormancy and it is due to cold or warm environments (FENNER; THOMPSON, 2005). Figure (1) showed that maximum germination was observed in hot water treatment which was (76.2\%) in Acacia nilotica and (64.3\%) in Faidherbia albida in hot water treatment followed by cold water in which it was $(62.4 \%)$ in A. nilotica and $(52.1 \%)$ in F. albida. In mechanical treatment A. nilotica was recorded with (54.3\%) followed by F. albida with (38.1\%), sulphuric acid treatment produced $(34.2 \%)$ in A. nilotica and $(28.1 \%)$ in F. albida and in control treatment A. nilotica was observed with $(22.8 \%)$ and F. albida with (12.6\%).

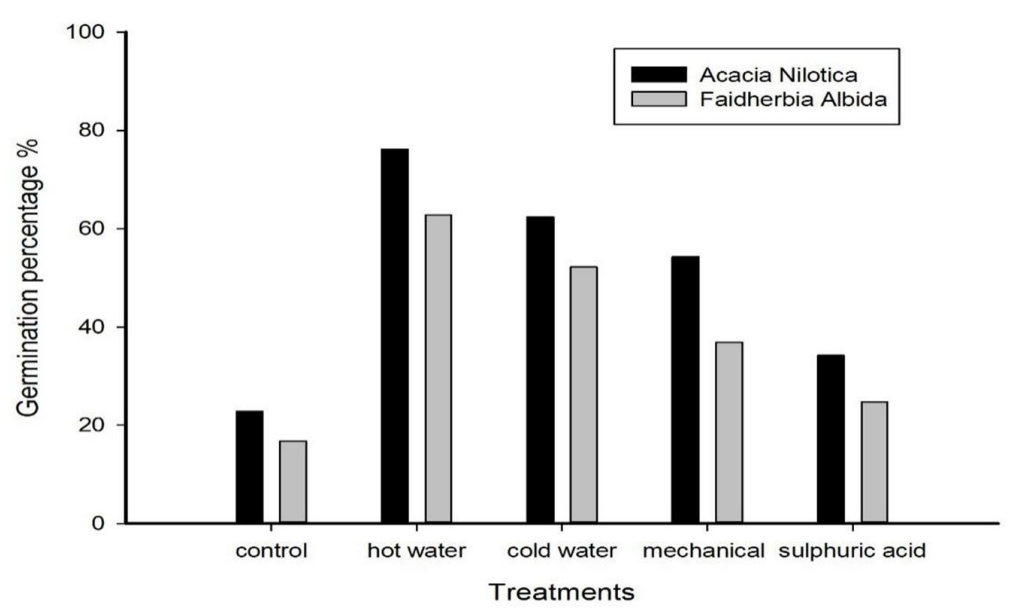

Figure-1 Germination rate of A.nilotica and F.albida affected by various seed treatments

Figura-1 Taxa de germinação de A.nilotica e F.albida afetadas por vários tratamentos de sementes

\section{Survival percentage}

Survival percentage is an important parameter to determine that how many plants survived in different treatments after a particular duration. Figure (2) showed that maximum survival percentage $(62.8 \%)$ was recorded in A. nilotica as compare to (51.8\%) in F. albida in hot water treatment followed by cold water in which it was (52.2\%) in A. nilotica and (40.9\%) in F. albida. In mechanical treatment A. nilotica was recorded (36.9\%) followed by F. albida (29.8\%), in sulphuric acid treatment (24.8\%) in A. nilotica and (18.6\%) in F. albida and in control treatment A. nilotica was observed with (16.8\%) and F. albida with (8.8\%). 


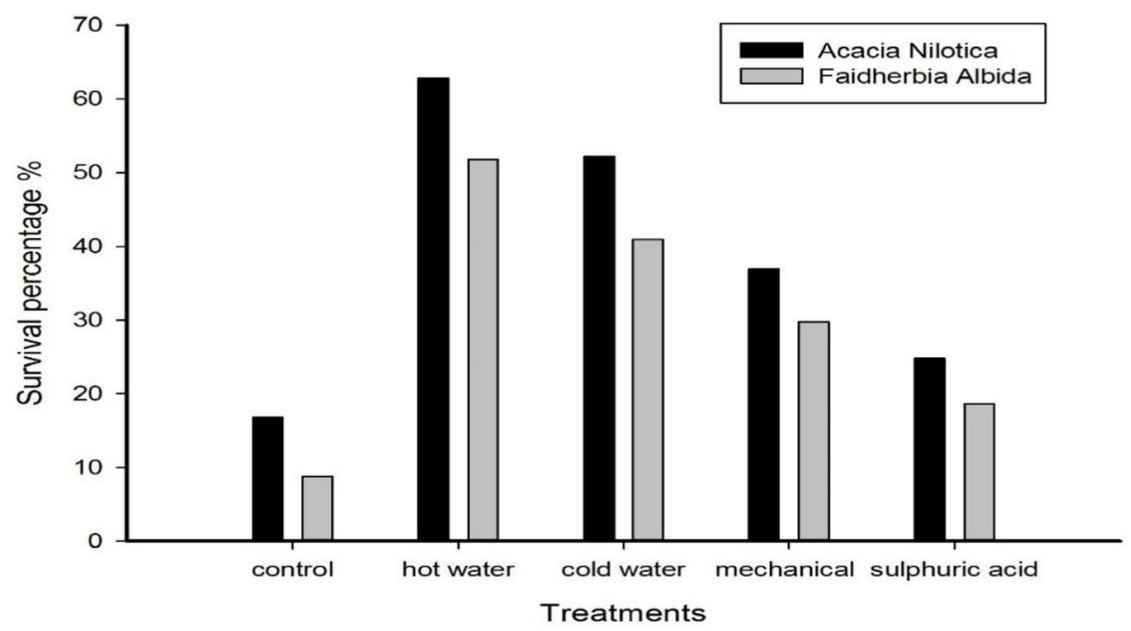

Figure-2 Survival rate of A.nilotica and F.albida affected by various seed treatments

Figura-2 Taxa de sobrevivência de A.nilotica e F.albida afetados por vários tratamentos de sementes

\section{Plant height}

To examine the growth of the plants, height is a significant factor. Plants with lesser height are considered less vigorous and under stress produced by growth preventive factors, while plants having extra height are considered healthy. In figure (3) height of plant which was maximam at $9.99 \pm 1.36 \mathrm{~cm}$ was noted in A. nilotica and $6.6 \pm 0.69 \mathrm{~cm}$ in F. albida in treatment with hot water followed by the treatment with cold water in which it was $9.09 \pm 1.43 \mathrm{~cm}$ in A. nilotica and $5.91 \pm 0.83 \mathrm{~cm}$ in F. albida. In Mechanical treatment it was $8.1 \pm 0.86 \mathrm{~cm}$ in A. nilotica and $5.1 \pm 0.81 \mathrm{~cm}$ in F. albida. In sulphuric acid treatment plant height was $4.88 \pm 1.11 \mathrm{~cm}$ in A. nilotica and $2.92 \pm 0.68 \mathrm{~cm}$ in F.albida and in control it was with $4.12 \pm 0.36 \mathrm{~cm}$ in A. nilotica and F. albida $2.39 \pm 0.11 \mathrm{~cm}$.

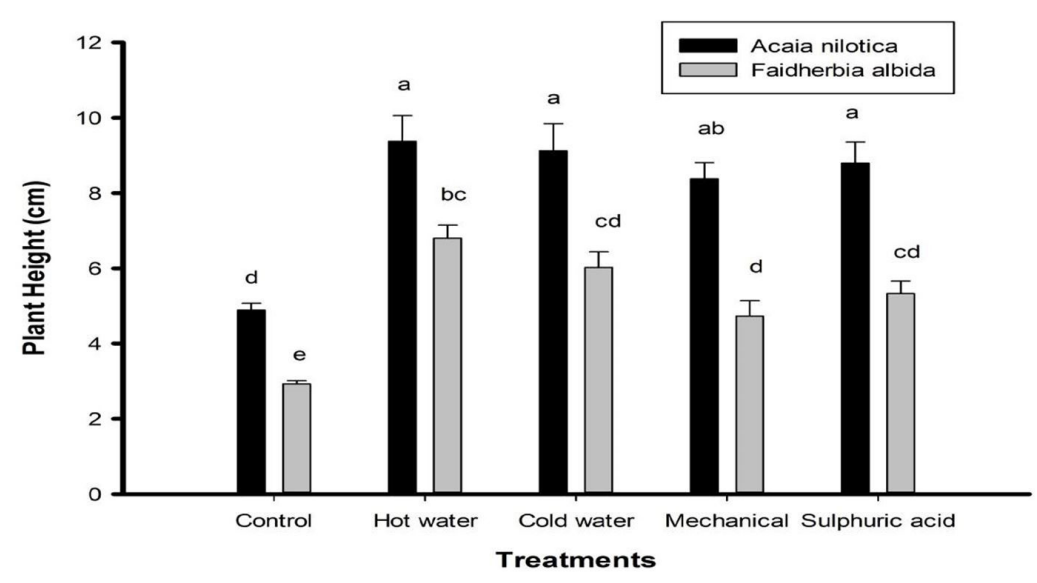

Figure-3 Plant height of A.nilotica and F.albida affected by various seed treatments

Figura-3 Altura da planta de A.nilotica e F.albida afetadas por vários tratamentos de sementes

\section{Number of branches}

Branches is the main source of timber. It offers sustenance, vigor, canopy cover to the plant. It assists leaves by exposing themselves to sunlight. The branch produces numerous roles in the plant by diverse means. Plants having extended branch reduces leaves overlap. Figure (4) displayed maximum number of branches $8.5 \pm 1.03$ that was recorded in A. nilotica as compare to the F. albida with $3.57 \pm 1.42$ in hot water treatment followed by cold water in which it was $8.09 \pm 1.42$ in A. nilotica and 3.14 \pm 0.43 in F. albida. In mechanical treatment maximum number of branches was recorded in A. nilotica $7.29 \pm 1.27$ followed by F. albida $3.06 \pm 0.42$, sulphuric acid treatment produced $3.71 \pm 1.02$ in A. nilotica and $2.68 \pm 0.46$ in F. albida and in control treatment A. nilotica with $3.3 \pm 0.17$ and $F$. albida with $2.31 \pm 0.47$ was observed. 


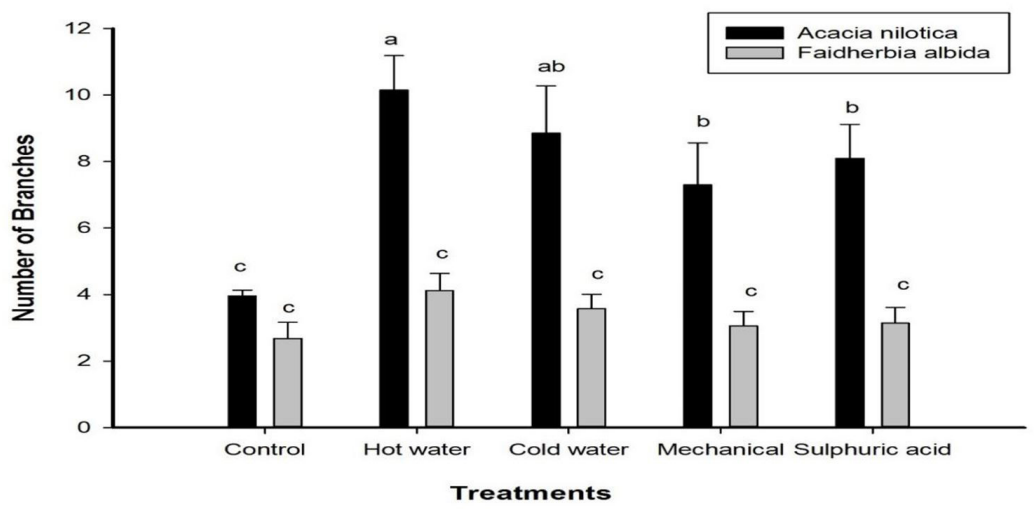

Figure-4 Number of branches of A.nilotica and F.albida affected by various seed treatment Figura-4 Número de ramos de A.nilotica e F.albida afetados por vários tratamentos de sementes

\section{Root length}

Roots offer sustenance to plant and it is also used as storage organs of the plant. Length of root is a significant aspect for healthier plant development as it is the necessary plant organ on which its strength to anchor in soil rest upon. Figure (5) showed that maximum root length $8.5 \pm 1.47 \mathrm{~cm}$ was recorded in A. nilotica as compared to the F. albida with $4.59 \pm 0.73 \mathrm{~cm}$ in the treatment of hot water followed by cold water treatment in which it was $8.09 \pm 1.37 \mathrm{~cm}$ in A. nilotica and $4.1 \pm 0.68 \mathrm{~cm}$ in F. albida. In mechanical treatment it was recorded with A. nilotica $7.22 \pm 0.97 \mathrm{~cm}$ and $F$. albida with $3.78 \pm 0.97 \mathrm{~cm}$, sulphuric acid treatment was observed with $3.96 \pm 1.62 \mathrm{~cm}$ in A. nilotica and $2.43 \pm 0.81 \mathrm{~cm}$ in F. albida and in control treatment A. nilotica with $3.11 \pm 0.16 \mathrm{~cm}$ and $F$. albida with $2.12 \pm 0.16 \mathrm{~cm}$ was observed.

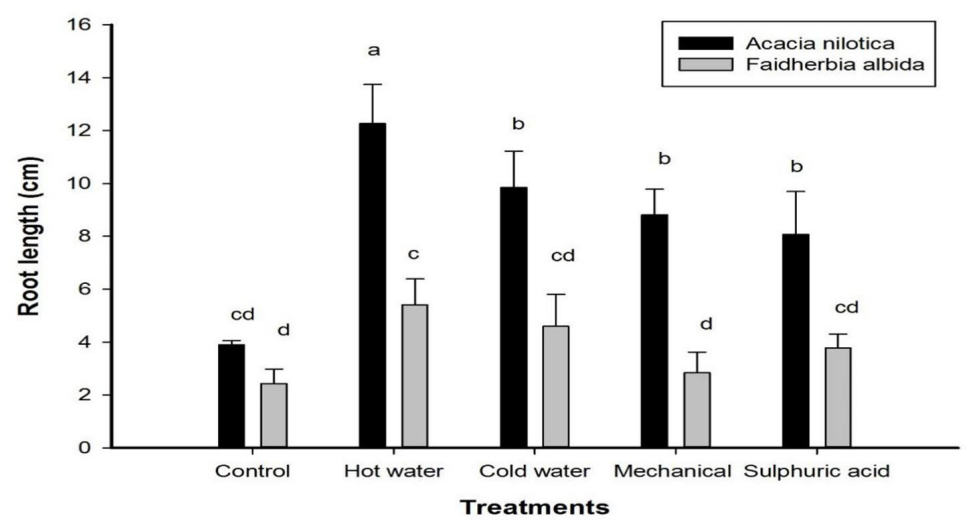

Figure-5 Root length of A.nilotica and F.albida affected by various seed treatments

Figura-5 Comprimento da raiz de A.nilotica e F.albida afetados por vários tratamentos de sementes

\section{Shoot fresh weight}

Fresh weight of shoot is a significant indicator of production of biomass and plant growth. Both species of Acacia showed major variations in performance for fresh weight of shoot in all treatments. Fresh weight of shoot at the end of the trial was calculated that showed variations. Maximum shoot fresh weight $7.42 \pm 1.58$ gm was noted in A. nilotica as compare to the Falbida which showed $5.32 \pm 0.88 \mathrm{gm}$ in treatment with hot water. In treatment with cold water it was $7.01 \pm 0.51 \mathrm{gm}$ in A. nilotica and $5.02 \pm 1.39 \mathrm{gm}$ in F. albida. In mechanical treatment it was recorded $6.77 \pm 0.19 \mathrm{gm}$ in A. nilotica and $4.38 \pm 1.28 \mathrm{gm}$ in F. albida, sulphuric acid treatment was observed with $3.55 \pm 0.36 \mathrm{gm}$ in A. nilotica and $3.16 \pm 1.30 \mathrm{gm}$ in F. albida and in control treatment A. nilotica with $3.17 \pm 0.24 \mathrm{gm}$ and F. albida with $2.97 \pm 0.37 \mathrm{gm}$ was observed. Average recorded fresh weight of shoot in Acacia nilotica was $7.04 \mathrm{gm}$ while in Faidherbia albida $4.8 \mathrm{gm}$. Figure (6). 


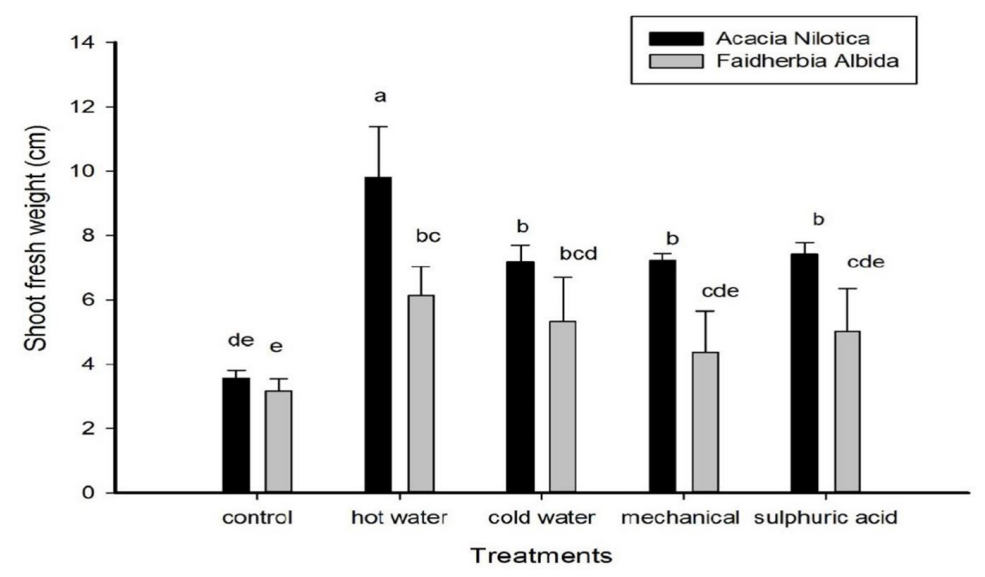

Figure-6 Shoot fresh weight of A.nilotica and F.albida affected by various seed treatments Figura-6 atirar peso fresco de A.nilotica e F.albida afetados por vários tratamentos de sementes

\section{Root fresh weight}

Plants with extra fresh weight of root have fast growing whereas plants with reduced fresh weight results in slow development and less production of biomass. The roots were weighed instantly after uprooting. Maximum Root fresh weight $7.56 \pm 0.92 \mathrm{gm}$ was recorded in A. nilotica compare to F. albida with $6.44 \pm 1.03 \mathrm{gm}$ in treatment with hot water followed by cold water treatment in which it was $6.1 \pm 0.88 \mathrm{gm}$ in A. nilotica and $4.77 \pm 0.49 \mathrm{gm}$ in F. albida. In mechanical treatment it was recorded $5.01 \pm 1.06 \mathrm{gm}$ in A.nilotica and $4.75 \pm 0.68 \mathrm{gm}$ in F. albida. In sulphuric acid treatment it was observed $3.65 \pm 0.92 \mathrm{gm}$ in A. nilotica and $3.16 \pm 0.93 \mathrm{gm}$ in $F$. albida and in control treatment A. nilotica with $3.12 \pm 0.19 \mathrm{gm}$ and $F$. albida with $3.01 \pm 0.09$ gm was observed.

Average recorded fresh weight of root in Acacia nilotica was $6.38 \mathrm{gm}$ while in Faidherbia albida $4.9 \mathrm{gm}$. Figure (7).

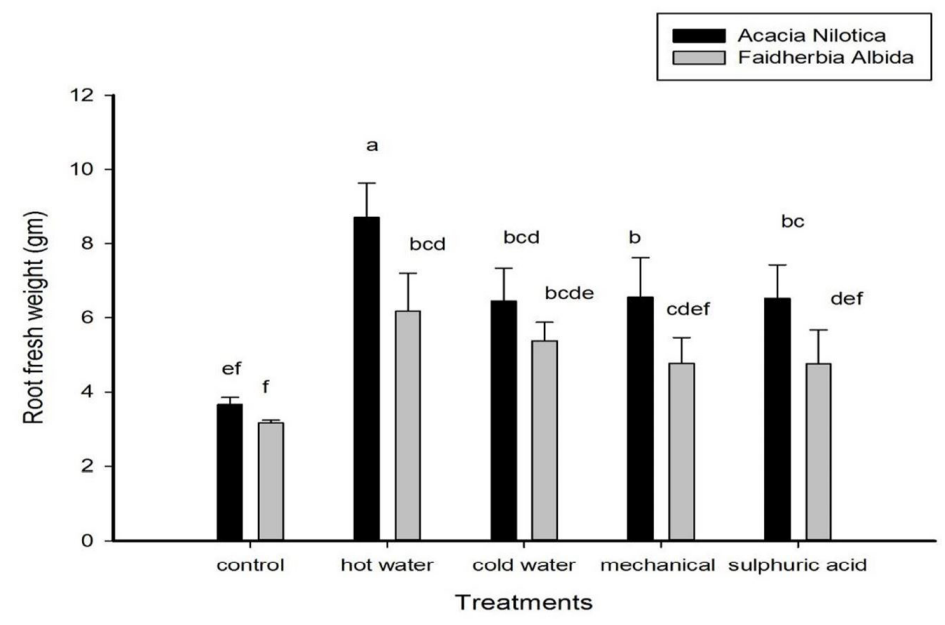

Figure-7 Root fresh weight of A.nilotica and F.albida affected by various seed treatments

Figura-7 Peso fresco da raiz de A.nilotica e F.albida afetados por vários tratamentos de sementes

\section{Root shoot ratio}

Root shoot ratio is a comparative examination among the above ground and the underground portion of the plant as well as a sign of the strength, vigor and plant development. If the value of root shoot become lesser, it indicates that the shoot of the plant has more length than the root of the plant. The influence of species on the root-shoot ratio was significant. After comparing both species root shoot ratio it became clear that maximum root-shoot ratio $0.94 \pm 0.37$ was recorded in A. nilotica as compare to the F. albida with $0.69 \pm 1.35$ in treatment with hot water followed by cold water treatment in which it was $0.88 \pm 1.67$ in A. nilotica and $0.57 \pm 1.06$ in F. albida. In mechanical treatment it was 
recorded $0.8 \pm 3.02$ in A. nilotica and $0.48 \pm 0.65$ in F. albida. In sulphuric acid treatment $0.69 \pm 2.41$ in A. nilotica and $0.42 \pm 0.45$ in F. albida and in control treatment for A. nilotica $0.49 \pm 0.38$ and for F. albida $0.31 \pm 0.17$ was observed. Figure (8)

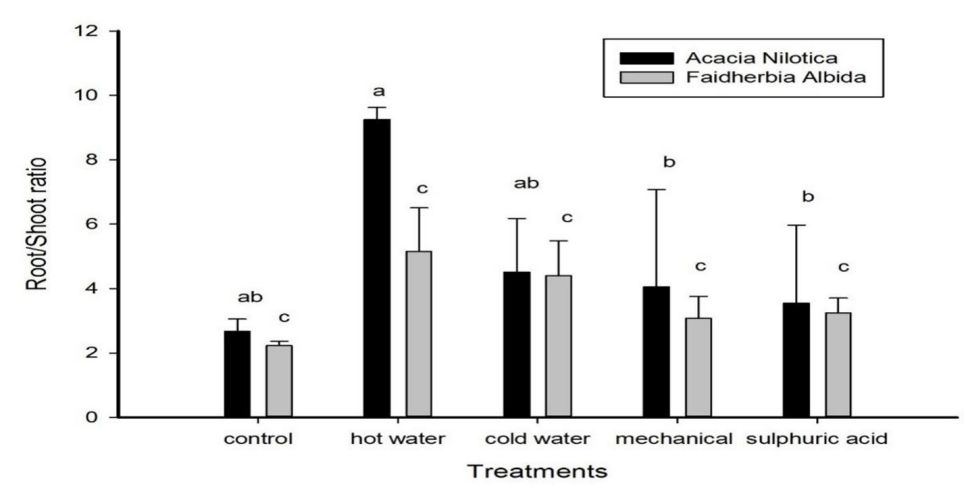

Figure-8 Root shoot ratio of A.nilotica and F.albida affected by various seed treatments

Figura-8 Relação de raiz de raízes de A.nilotica e F.albida afetadas por vários tratamentos de sementes

\section{DISCUSSION}

Some researchers discussed that pre-sowing treatment on seed can improve the growth rate, development process and the dormancy of seed. Though, dormancy of seed varies with degree of seed drying and phase of seed maturity. Therefore, pre-treatment must be adjusted on the base of the status of seed dormancy. The conclusions of the current research also indicated that seeds of A. nilotica and F. albida in different treatments improved percentages significantly. Numerous treatments of seed are being used for quick and constant germination. Maximum germination was observed in hot water treatment which was (76.2\%) in Acacia nilotica and (64.3\%) in Faidherbia albida followed by cold water in which it was (62.4\%) in A. nilotica and (52.1\%) in F. albida. In mechanical treatment. Seed dormancy is determined by many endogenous factors so the methods of removing it are different. The moist pre-chilling has been anciently used to break the dormancy (ZOHNER et al., 2016). The effects of several pre-sowing treatments on germination have been conducted by some researchers on different tropical forest. Our results are supported by (KHAN et al., 2001; KOIRALA et al., 2000) who revealed that because of hard seed coat of some trees their germination is poor. Water soaking is a method of leaching out chemical inhibitors frequently in seeds and fruits and it enhances the plant root length (SCHMIDT, 2000). Though, soaking in water for 12 and 24 hours is not an ideal pre-sowing treatment for common tested species, nevertheless it was enough to give seed-coat penetrable in the conditions where physical dormancy is comparatively fragile, e.g. Sesbania sesban. Extended contact for several hard-coated Australian species for two minutes' boiling was found higher to 1 minute, and some species are pre-treated by boiling for up to five minutes, boiling of water at $80^{\circ} \mathrm{C}$ for 120 minute indicated some potential with Acacia ampliceps, though this procedure produced mortality and severe fungal complications with A. stenophylla. In this experiment we found that A. nilotica was better as compared to F. albida. Long time of soaking from 20 to 25 minutes enhanced growth proportion significantly particularly the length of the root. Response of A. nilotica to hot water pre-sowing treatment was higher than the F. albida. Dipping in hot water beyond 15 minutes makes the seeds dull and shallowly pitted. Current findings support the result of (MCGAHUEY, 1985) who revealed that, in Australia this practice is used for species with thick seed-coats such as A.stenophylla. Similarly, acid and hot water treatment can also overcome physical seed dormancy and it enhances root weight of the plant (AIRI et al., 2009). Numerous findings have validated that pre-sowing treatments increased the growth of hard seed coat and enhances the size of the root, however the untreated drupes developed gradually and unevenly (HOSSAIN et al., 2005). Along with the hot water treatment, cold water treatment was also better. (AMUSA, 2010) Found that soaking seeds in cold water increased the germination of Afzelia africana seeds as a result of of lack of oxygen. In this trail hot water treatment along with treatment in cold water was the most successful in enhancing root weight and improving growth. 


\section{CONCLUSIONS}

A. nilotica and F. albida are vital tree species for social forestry. Between the five pre-sowing treatments, hot water treatment, cold water treatment and mechanical treatment performed better in germination of seeds without significant change amongst these three. Though, the use of sulphuric acid is risky and troublesome. In contrast, germination of seed in hot water treatment is relatively simple and economical. From this research, treatment with hot water is suggested for the germination of A. nilotica and F. albida seeds.

\section{REFERENCES}

AIRI, S; BHATT, I. D.; BHATT, A.; RAWAL, R. S; DHAR, U. Variations in seed germination of Hippophae salicifolia with different presoaking treatments. Journal of Forestry Research, v. 20, n.1, p. 27-30, 2009.

AMUSA, T. O. Effects of three pre-germination treatments techniques on dormancy and germination of seeds of Afzelia africana. Journal of Horticulture and Forestry, v. 3, p. 96-103, 2010.

AREF, I. M; ATTA, H. A; SHAHRANI, T. A; MOHAMED, A. I. Effects of seed pretreatment and seed source on germination of five Acacia spp. African Journal of Biotechnology, v. 10, n. 71, p. 15901-15910, 2011.

FENNER, M; THOMPSON, K. The ecology of seeds. Cambridge: Cambridge University Press, 2005. 98 p.

HOLDSWORTH, M. J.; BENTSINK, L; SOPPE, W. J. Molecular networks regulating Arabidopsis seed maturation, after-ripening, dormancy and germination. New Phytologist. v. 179, n.1, p.33-54, 2008

HOSSAIN, M. A.; AREFIN, M. K.; KHAN, B.M.; RAHMAN, M. A. Effects of seed treatments on germination and seedling growth attributes of Horitaki (Terminalia chebula Retz.) In the nursery. Research Journal of Agriculture and Biological Sciences. v. 1, n. 2, p.135-141, 2005.

KARAGUZEL, O. S.; CAKMAKCI, S. A; ORTACESME, V. E; AYDINOGLU, B. I. Influence of seed coat treatments on germination and early seedling growth of Lupinus varius L. Pakistan Journal of Botany, v. 36, n.1, p. 65-74, 2004.

KEELEY, J. E.; FOTHERINGHAM, C. J. Role of fire in regeneration from seed. Seeds: the ecology of regeneration in plant communities. In: FENNER, M. (Ed.). Seeds: the ecology of regeneration in plant communities. London: CABI Publishing, 2000. Cap. 13, p. 311-328.

KHAN, B. M; KOIRALA, B; HOSSIAN, MK. Effect of different pre-sowing treatments on germination and seedling growth attributes in Ghora Neem (Melia azedarach L.). Malaysian Forester, v. 64, n.1, p.14-21, 2001.

KOIRALA, B; HOSSAIN, MK; HOSSAIN, MS. Effects of different pre-sowing treatments on Adenanthera pavonia L. seeds and initial seedling development in the nursery. Malaysian Forester, v. 63, n.2, p. 82-91, 2000.

KULKARNI; M. G, SPARG; S. G; VAN STADEN, J. Germination and post-germination response of Acacia seeds to smoke-water and butenolide, a smoke derive compound. Journal of Arid Environments, v. 69, n. 1, p. 177-187, 2007.

MCGAHUEY, M. Assessment of the Acacia albida extension projects in Chad. Washington DC: Chemonics International, 1985.

MERRIT, D. J.; KRISTIANSEN, M.; FLEMATTI, G. R.; TURNER, S. R.; GHISALBERTI, E. L.; TRENGOVE, RD; DIXON, KW. Effects of a butenolide present in smoke on light-mediated germination of Australian Asteraceae. Seed Science Research, v. 16, n. 1, p. 29-35, 2006.

NELSON, D. C; RISEBOROUGH, J. A; FLEMATTI, G. R; STEVENS, J; GHISALBERTI, E. L; DIXON, K. W; SMITH, S. M. Karrikins discovered in smoke trigger Arabidopsis seed germination by a mechanism requiring gibberellic acid synthesis and light. Plant physiology, v.149, p 863-873, 2009.

RIVAS, M; REYES, O; CASAL, M. Influence of heat and smoke treatments on the germination of six leguminous shrubby species. International Journal of Wildland Fire, v. 15, n. 1, p. 73-80, 2006.

Sci. For., Piracicaba, v. 47, n. 122, p. 374-382, jun. 2019

DOI: doi.org/10.18671/scifor.v47n122.20 
Gilani et al. - Effects of pre-sowing treatments on seed germination and

Morphological growth of Acacia nilotica and Faidherbia albida

SCHMIDT, L. Dormancy and pre-treatment. In: OLSEN, K. (Ed.). Guide to handling of tropical and subtropical forest seed. Humblebaek: Danida Forest Seed Centre Denmark. 2000. p.42.

SCHUTZ, W. Germination responses of temperate Carex-species to diurnally fluctuating temperatures-a comparative study. Flora, v. 194, n. 1, p. 21-32, 1999.

VAN STADEN, J; BROWN, N. A.; JAGER, A. K.; JOHNSON, T. A. Smoke as a germination cue. Plant Species Biology. v. 15, n. 2, p.167-178, 2000.

ZOHNER, C. M; BENITO, B. M; FRIDLEY, J. D; SVENNING, J. C; RENNER, S. S. Historical climates explain contrasting dormancy-breaking requirements in North American, Asian, and European woody species. EGU General Assembly Conference, v. 18, 2016.

ZULOAGA-AGUILAR, S; BRIONES, O; OROZCO-SEGOVIA, A . Effect of heat shock on germination of 23 plant species in pine-oak and montane cloud forests in western Mexico. International Journal of Wildland Fire, v. 19, n. 6, p. 759-773, 2010.

Received: 03/14/2018

Accepted: 10/31/2018 